\title{
O historiador e o trato com as fontes pictóricas - a alternativa do método documentário
}

\author{
Vinicius Liebel \\ Pontifícia Universidade Católica do Rio Grande do Sul, Porto Alegre - RS, Brasil
}

\section{RESUMO}

Neste artigo é apresentado e debatido o Método Documentário de Análise de Imagem desenvolvido por Ralf Bohnsack, pesquisador da Freie Universität Berlin, e algumas de suas possibilidades para os estudos de História e demais áreas das Ciências Humanas. A busca pelo sentido documentário da imagem, para além do sentido imanente, caracteriza o método que aponta para a análise da visão de mundo e do habitus do grupo produtor da fonte. Desta forma, passa-se da simples interpretação da imagem para o estudo aprofundado das características de tal grupo, suas ideias, açôes, seus conceitos e preconceitos. $\mathrm{Na}$ tentativa de aproximar o método das ciências históricas e políticas, apresentamos uma análise de uma charge como exemplo. Tal forma de representaçáo foi escolhida pelo fato de poucas imagens serem táo marcadamente políticas e ao mesmo tempo representativas de um momento e um grupo social quanto as charges. A análise da imagem pretende, assim, demonstrar a abrangência que uma fonte dessa natureza pode apresentar, bem como a efetividade da utilização do método documentário na busca por sua ampla compreensão.

Palavras-chave: método documentário; análise de imagens; nazismo; charges; história cultural do político.

\section{ABSTRACT}

This paper presents, and discusses, the Documentary Method for Analysis of Pictures, developed by Ralf Bohnsack, a researcher at Berlin Free University, and some of its possibilities for studies in History and other areas of Humanities. The search for the documentary meaning of an image, beyond the immanent one, characterizes the method, which is directed towards the analysis of the worldview, and the habitus, of the social group that produced the image. The method goes from the simple interpretation of the picture to the in-depth study of the characteristics of the social group that produced it: its ideas,

DOI - http://dx.doi.org/10.1590/2237-101X017033003

Artigo recebido em 29 de setembro de 2014 e aprovado para publicaçáo em 3 de novembro de 2016.

* Doutor em Ciência Política pela Universidade Livre de Berlim (FU-Berlin), professor colaborador do PPG-

-História da PUCRS, bolsista CAPES/PNPD na mesma instituição. E-mail: liebel@daad-alumni.de. 
actions, concepts, and prejudices. In an attempt to bring the method to History and Political Science, we present the analysis of a cartoon as an example. The cartoon was chosen for its political features, as well as for its representation of a period and a social group. The analysis of the picture seeks to demonstrate the comprehensiveness of such a source, as well as the effectiveness of the documentary method to understand the image.

Keywords: documentary method; interpretation of pictures; nazism; political cartoons; cultural history of politics.

Na busca por um método eficiente de análise de imagens, os pesquisadores das Ciências Humanas se deparam com um campo problemático. Os métodos e teorias nessa área são poucos e normalmente não englobam os diferentes tipos de imagem. No tocante às metodologias qualitativas o cenário não é diferente. Segundo Ralf Bohnsack,

Quando se considera especificamente o desenvolvimento dos métodos de interpretaçáo de imagens no campo das pesquisas qualitativas, chega-se a uma observaçáo impressionante e paradoxal. Percebe-se que o estabelecimento e o aperfeiçoamento dos métodos qualitativos nos últimos 25 anos levaram, em grande medida, a uma marginalização das imagens. ${ }^{1}$

Tal marginalização das imagens na sua condição de fonte de análise válida está presente nos mais diversos campos das Humanidades, desde a Sociologia e a Ciência Política até a História, com a excessão óbvia da História da Arte. Esta resistência à fonte pictórica surge ainda em grande parte como uma herança da sociedade científica novecentista e sua concepção de que a "verdade" só poderia ser extraída das fontes escritas. Desta forma, a legitimidade da fonte imagética ainda é colocada em questão, mesmo que a sociedade seja cada dia mais "visual". As placas de anúncios publicitários, os filmes e naturalmente a televisão são elementos cada vez mais presentes no cotidiano e representam uma parcela cada vez maior do conjunto social. Como exemplo da importância das fontes pictóricas na análise de uma sociedade podemos tomar os dados estatísticos da A. C. Nielsen Co., ${ }^{2}$ que mostram que um norte-americano passa em média três horas e quarenta e seis minutos por dia em frente à televisão. Isso significa nove anos ininterruptos na vida de uma pessoa de sessenta e cinco anos. Somando-se a exposição a outras fontes visuais, como revistas ilustradas, panfletos, e mesmo jornais e placas publicitárias, esse número deve subir ainda mais. Com a configuração desta sociedade imagética, o elemento pictórico não pode ser deixado de lado em sua

\footnotetext{
${ }^{1}$ BOHNSACK, Ralf. Rekonstruktive Sozialforschung. Opladen: Budrich, 2007, p. 155. Trad. livre do autor.

${ }^{2}$ Disponível em: <http://www2.acnielsen.com/site/index.shtml>. Acesso em: 15 set. 2009.
} 
análise e, desta forma, a análise de imagens passa a ser não apenas uma pesquisa legítima como também essencial para compreender as estruturas e dinâmicas da sociedade e do período no qual ela se insere. ${ }^{3}$

Para tanto, as imagens se mostram fontes tão representativas e legítimas quanto os textos, talvez mesmo mais, uma vez que aquelas alcançam um maior número de pessoas pela sua própria natureza, exigindo competências menos complexas para seu entendimento que as fontes textuais, que demandam pelo menos o conhecimento da língua e da escrita. Além disso, a linguagem da imagem é mais direta que a do texto, sua mensagem é normalmente captada e entendida mais rapidamente. O público das imagens é maior, sendo formado também por crianças e por aqueles que não detêm as condiçôes necessárias para "decifrar" os textos. A presença e a influência das imagens sobre a sociedade e sobre os indivíduos podem ser dessa forma percebidas, bem como a importância da análise deste tipo de fontes para a compreensão das estruturas mentais e práticas que envolvem a sociedade em questão.

O recente (e ainda tímido) interesse das Ciências Humanas por este tipo de fonte reflete essa necessidade. Na Sociologia, na História, como também no campo da Ciência Política, a análise de imagens caminha em passos lentos, ainda que Mitchell ${ }^{4}$ tenha propagado, com razão, uma virada pictórica (pictorial turn) nas Humanidades. Na busca por uma compreensão mais abrangente dos diferentes fenômenos sociais que, muitas vezes, não se fazem tão claros através dos números e das estatísticas, a análise dos elementos constitutivos da sociedade mostra-se um passo importante. Como as constataçôes feitas anteriormente comprovam, as imagens são fontes privilegiadas para este intento.

Por este motivo, um método de análise de imagens que ao mesmo tempo respeite as especificidades das pesquisas históricas e forneça as ferramentas que possibilitem o desenvolvimento dessas reflexôes com o foco nas fontes imagéticas se faz necessário. Sendo o campo mais desenvolvido das Ciências Humanas no tocante às análises pictóricas, é natural que a base de tal método seja constituída por teorias e metodologias arroladas por historiadores da Arte. O método documentário concebido por Ralf Bohnsack ${ }^{5}$ procura da mesma forma

\footnotetext{
${ }^{3}$ Tais análises podem tomar caminhos diferentes dependendo da natureza da imagem, e a discriminação da fonte assume importância ímpar, especialmente quanto à sua proveniência e legitimidade. Quanto às imagens computadorizadas e especialmente às "montagens" o rigor deve ser mantido, mas isso não as exclui da possibilidade de análise por também poderem ser representativas da sociedade e/ou grupo onde foram produzidas. Também as suas possibilidades de recepção podem levar a diferentes caminhos de pesquisa; ainda que argumentos sobre a forte tendência à crença na veracidade da imagem soem à primeira vista corretos, alguns casos de imagens satíricas e/ou caricatas parecem não dar espaço para tal relação.

${ }^{4}$ MITCHELL, William John Thomas. Picture Theory. Chicago: Chicago University Press, 1994, p. 11-34.

${ }^{5}$ Idealizador da vertente metodológica aqui destacada e apresentada, Ralf Bohnsack é sociólogo e professor titular do departamento de Educação e Psicologia da Universidade Livre de Berlim (FU-Berlin). Fundador e coordenador da "Linha de Pesquisa Qualitativa em Educação" na mesma universidade, é autor de relevantes artigos em revistas especializadas nas áreas de Sociologia e Educação, concentrados principalmente em aspectos diversos da metodologia de pesquisa qualitativa. É ainda autor de livros importantes nas mesmas áreas, dentre os quais se destacam Rekonstruktive Sozialforschung (2007) e Qualitative Bild-und Videointerpretation (2009).
} 
uma aproximação com a História da Arte, especificamente com as obras de Erwin Panofsky e Max Imdahl. Sáo ainda de grande valia, acrescento, as obras de E. H. Gombrich e de Will Eisner, que se ocupam também da questão específica das charges e caricaturas, particularmente pertinente para a presente reflexão.

\section{O método documentário}

O método documentário tem como premissa principal a mudança do foco de análise do sentido imanente da fonte, ou seja, do "o que" a fonte é, para um outro nível analítico no qual o pesquisador se ocupa da natureza profunda e social da fonte, i.e., "trata-se da mudança da pergunta de o que (was) são os fenômenos ou acontecimentos sociais ou culturais para a pergunta como (wie) eles são produzidos."

Baseado no pensamento de Karl Mannheim e a sua Sociologia do Conhecimento, o método documentário visa a uma análise abrangente (qualitativa) do objeto. Segundo Mannheim, é possível apreender no processo de análise de um produto cultural, de um grupo social, de uma nação ou de qualquer que seja o elemento pesquisado, "três níveis de sentido": a) o nível de sentido objetivo ou o que pode ser percebido a partir da simples observação, b) o nível de sentido expressivo, e aqui se englobam as manifestaçôes corporais, a linguagem corporal e os diferentes significados que uma palavra pode tomar, e c) o nível de sentido documentário, i.e., a interpretação e documentação da fonte bem como de sua forma de produção (Herstellungsweise) no seu próprio contexto. Esse é o ponto principal da análise. As duas primeiras estruturas de sentido, a objetiva e a expressiva, podem fornecer detalhes e informaçôes distintas e importantes, mas a fonte pode também gerar uma interpretação completamente diferente quando analisada sob o prisma de seu próprio período, sob a perspectiva de seu próprio momento (Jetzt-Perspektive).

A reconstrução do momento, i.e., do campo de experiências conjuntivas, surge então como parte primordial do processo de interpretação e pode, além disso, no sentido proposto por Bohnsack, possibilitar a mudança do foco de análise: deixa-se de conduzir uma pesquisa sobre o que a fonte é e passa-se a uma outra sobre como ela foi produzida. $\mathrm{O}$ ordenamento histórico do fenômeno é aqui um postulado, pois apenas através desta reconstrução pode-se obter uma representação precisa do sentido da ação e/ou da produção. Tal reconstrução contextual não se refere apenas ao estudo de seu período e de seu "lugar”, mas também de suas estruturas mentais e praxiológicas, que têm evidente papel na

\footnotetext{
${ }^{6}$ BOHNSACK, Ralf. Rekonstruktive Sozialforschung, op. cit., p. 158. Trad. livre do autor.

${ }^{7}$ MANNHEIM, Karl. Wissenssoziologie — Auswahl aus dem Werk. Berlim/Neuwied: Luchterhand, 1964, p. 104 et. seq. Ver também WELLER, Wivian. A contribuição de Karl Mannheim para a pesquisa qualitativa: aspectos teóricos e metodológicos. Sociologias, Porto Alegre, n. 13, jan-jun. 2005. Disponível em: <http:// www.scielo.br/scielo.php?script=sci_arttext\&pid=S1517-45222005000100011>. Acesso em: 16 out. 2012.
} 
sua "produção de sentido". Desta forma, é possível perceber que uma determinada fonte, açáo ou acontecimento só pode ser apreendido de maneira abrangente se os três níveis de sentido forem analisados.

Essa metodologia foi, até o momento, intensivamente trabalhada em pesquisas com grupos de discussão e entrevistas biográficas, onde as diferentes apreensões de sentido podem ser identificadas clara e pessoalmente pelo pesquisador: uma frase dita, por exemplo, pode ser tomada no sentido objetivo, ou seja, no seu significado literal, como pode também ser analisada em conjunto às expressóes corporais e do rosto, i.e., em seu sentido expressivo. Finalmente, pode ser tomada no sentido documentário, quando os dois níveis de sentido devem ser observados em seu contexto próprio e, baseado nas estruturas mentais do elemento em questão, diferentes interpretaçôes podem ser produzidas. ${ }^{8}$

A etapa documentária se justifica pelo fato de todo e qualquer grupo social se formar sobre estruturas mentais que exercem influência não apenas sobre suas mentalidades, mas também sobre suas ações. As relaçóes entre grupos sociais e tais estruturas foram exaustivamente estudadas. Destacam-se entre tais esforços a teoria praxiológica de Pierre Bourdieu, que lega à metodologia documentária o conceito de habitus, e a obra de Karl Mannheim, em especial suas análises sobre as visões de mundo (Weltanschaunngen). Para além desta base teórica, acrescenta-se aqui à metodologia de Bohnsack as ideias e análises de Cornelius Castoriadis ${ }^{10}$ e sua teoria do imaginário.

$\mathrm{O}$ conceito de habitus se relaciona às açôes do grupo. $\mathrm{O}$ imaginário tem aqui um papel determinista, pois lega ao grupo as imagens mentais que vão orientar em grande medida tais ações. Esses modelos mentais formam as concepçôes cotidianas de vida, ou seja, concepçôes tidas como correntes e "normais" de ação e de pensamento de um indivíduo e de seu grupo. Com isso o imaginário tem influência sobre a formação e/ou manutenção de um determinado modelo de açáo. O habitus surge, de um lado, como uma estrutura estruturada (opus operatum) que é determinada pelas açóes anteriores, mas de outro lado como uma estrutura estruturante (modus operandi) que fornecerá modelos para as ações.

Produto da história, o habitus produz práticas, individuais e coletivas, portanto, história, conforme os esquemas engendrados pela história; ele assegura a presença ativa das experiências passadas que, depositadas em cada organismo sob a forma de esquemas de percepção, de pensamento e de ação, tendem mais seguramente que todas as regras formais e todas as normas explícitas, a garantir a conformidade das práticas e sua constância através do tempo. ${ }^{11}$

\footnotetext{
${ }^{8}$ Essa modalidade do emprego do método documentário pode ser observada exemplarmente no trabalho de WELLER, Wivian. Minha voz é tudo que tenho. Belo Horizonte: EdUFMG, 2011.

${ }^{9}$ BOURDIEU, Pierre. Le sens pratique. Paris: Les Éditions de Minuit, 1980.

${ }^{10}$ CASTORIADIS, Cornelius. A instituição imaginária da sociedade. Rio de Janeiro: Paz e Terra, 1982.

${ }^{11}$ BOURDIEU, Pierre. Le sens pratique, op. cit., p. 91. Trad. livre do autor.
} 
As açóes sociais que se encontram no tempo presente do objeto seguem a tendência das açôes passadas, formando uma estrutura prática que tende a se reproduzir e a se projetar no futuro. A continuidade desta estrutura pode ser garantida por sua funcionalidade. Tão logo ela não encontre mais lugar na realidade presente, dá-se início a um processo de transformação estrutural em busca de uma adequação ao novo contexto. Esse fenômeno de mudança não é, naturalmente, imediato, podendo levar geraçôes para ser processado. Desta forma o habitus se justifica enquanto objeto de pesquisa, mostrando-se um eficiente demarcador no reconhecimento e na caracterização espaçotemporal.

Porque o habitus é uma capacidade infinita de engendrar em toda liberdade (controlada) produtos - pensamentos, percepçóes, expressóes, açôes — que sempre têm por limites as condiçóes histórica e socialmente situadas de sua produção, a liberdade condicionada e condicional que ele assegura é tanto distanciada de uma criação de imprevisível novidade quanto de uma simples reprodução mecânica dos condicionamentos iniciais. ${ }^{12}$

O imaginário, por sua vez, é o "conjunto de imagens visuais e verbais gerado por uma sociedade (ou parcela desta) na sua relação consigo mesma, com outros grupos humanos e com o universo em geral". ${ }^{13}$ Apesar de se manifestar no indivíduo, o imaginário é sempre uma estrutura coletiva, e não pode ser confundido nem com a capacidade individual de imaginação, ou seja, de criação e de ordenação de imagens e narrativas operadas no âmbito do indivíduo, nem com a somatória de todas as imaginaçóes. Ele se mostra assim uma instância determinante, uma reuniáo de imagens mentais e verbais que são correntemente tomadas como normais ou cotidianas, e com isso ajuda a definir a sociedade ou o grupo social que nele se insere. $\mathrm{O}$ habitus se deixa orientar por essa bagagem, pelas imagens que o imaginário provê.

Relação análoga podemos observar entre os conceitos de visão de mundo (Weltanschauung) e imaginário. Também aqui a ação da estrutura é delimitada pelo conjunto de imagens fornecido pelo imaginário. Segundo a descrição de Mannheim, a

Weltanschauung (de um período, de um grupo, etc.) é (...) uma linha estruturalmente ligada de conjuntos de vivências que forma simultaneamente a base conjunta de experiências de vida e de passagens de vida para uma variedade de indivíduos. A Weltanschaunng, assim, não é nem a totalidade de estruturas mentais presentes em um período nem o total de conjuntos de vivências estruturalmente ligadas que podem ser determinados tanto do lado da estrutura quanto do lado da constituição social de grupos. ${ }^{14}$

\footnotetext{
${ }^{12}$ Ibidem, p. 92. Trad. livre do autor.

${ }^{13}$ FRANCO JR., Hilário. Cocanha - a história de um país imaginário. São Paulo: Companhia das Letras, 1998, p. 16-17.

${ }^{14}$ MANNHEIM, Karl. Strukturen des Denkens. Frankfurt am Main: Suhrkamp Verlag,1980, p. 101.
} 
A Weltanschauung se apresenta assim como o modus operandi do pensar, uma estrutura localizada estruturalmente no campo das mentalidades e, nesse sentido, como um equivalente do habitus no nível mental. "Weltanschauung recobre o conjunto de quadros mentais - tanto intelectuais quanto éticos - nos quais os indivíduos e grupos, a cada dia, desenvolvem seu pensar e sua ação." ${ }^{15}$ Como seu semelhante praxiológico, é nas vivências, nas tradiçôes e nos exemplos que encontramos sua estruturação. Em um sentido mais amplo, é no campo do compartilhamento das experiências culturais de âmbito intelectual, moral, ideológico, educacional etc. que encontramos sua base social, ou seja, coletiva.

Assim, o imaginário se apresenta como grande conjunto de imagens no qual a Weltanschaunng se desenvolve e pode se distinguir perante outros elementos mentais através de sua qualidade pontual-contemporânea. Mas a relação simbiótica entre esses dois elementos tem o efeito de constante "renovador" do campo mental, pois é dela que novas representaçóes, ideias ou imagens surgirão. O imaginário, em seu papel de instância determinante, fornece o grupo de imagens e, com isso, a base para o desenrolar da Weltanschaunng. Esta, por sua vez, no papel de modus operandi do pensamento, reproduz seus padróes, mas também fomenta o desenvolvimento, através das experiências coletivas, de novas imagens mentais, representaçôes ou ideias que irão servir como produto e "abastecimento" do imaginário. Este cumpre assim o papel descrito por Castoriadis:

O imaginário (...) não é imagem de. É criação incessante e essencialmente indeterminada (social-histórica e psíquica) de figuras/formas/imagens, a partir das quais somente é possível falar-se de "alguma coisa". Aquilo que denominamos "realidade" e "racionalidade" são seus produtos. ${ }^{16}$

Apesar de sua natureza atemporal, o imaginário pode ser tomado temporalmente para análise. Dessa forma é possível se falar de imaginário da Idade Média ou da Renascença, por exemplo. Também sua discriminação geográfica ou social é possível, como em "imaginário alemão" ou "imaginário da classe média". Isso faz alusão não apenas às imagens produzidas no período de tempo ou pelo grupo social em questáo, mas também às imagens que influenciaram o dado grupo. Entretanto, Castoriadis lembra ainda que "todo pensamento da sociedade e da história pertence em si mesmo à sociedade e à história. Todo pensamento, qualquer que seja ele e qualquer que seja seu "objeto", é apenas um modo e uma forma do fazer social-histórico" ${ }^{17}$ Com essa frase, Castoriadis se aproxima do conceito mannheimiano de Weltanschauung e de sua qualidade de contemporaneidade, de sua natureza enquanto modus operandi do pensar. Ele delimita dessa forma os "campos de influência" tanto do

\footnotetext{
${ }^{15}$ MANDROU, Robert. Introduction à la France moderne, 1500-1640. Essai de psychologie historique. Paris: A. Michel. 1998, p. 334.

${ }^{16}$ CASTORIADIS, Cornelius. A instituiçâa imaginária da sociedade, op. cit., p.13.

${ }^{17}$ Idem.
} 
imaginário quanto da Weltanschauung. Os diferentes elementos dos níveis mental e prático mantêm entấo uma relação constante e interativa.

A análise dos elementos mentais aqui discutidos possibilita um olhar abrangente sobre o objeto de estudo. Levando em conta esses elementos, é possível apreender a mentalidade do grupo estudado e assim compreender o processo de constituição de seus produtos culturais e das açóes, ou seja, chega-se finalmente à questão do "como" (Wie-Frage) sugerida por Bohnsack. O sentido documentário e a historicidade do documento podem ser reconhecidos, especificamente, através da análise da visão de mundo e do habitus. O imaginário, por sua vez, parece não ter à primeira vista uma relevância central no desenrolar de algumas pesquisas, visto que está relacionado primordialmente com o saber implícito. Entretanto, o reconhecimento e a análise deste elemento podem desempenhar um papel central no estudo do documento, o que fica ainda mais evidenciado no caso de uma fonte pictórica, como poderá ser constatado a partir do exemplo na segunda parte deste texto.

Em todas as técnicas empregadas pelo método documentário (análise de imagens, discussão em grupo, entrevista biográfica etc.), a busca pelo contexto e por suas especificidades se mostra o ponto central do procedimento. Segundo Bohnsack,

Em uma entrevista individual eu posso compreender adequadamente a expressão individual no contexto de uma narrativa ou de uma longa representação. Em uma discussão em grupo pode se tornar mais claro para mim que eu assisto ao indivíduo na comunicação com qualquer outro com quem ele ou ela se comunique no cotidiano, ou seja, dentro de seu contexto social habitual, por exemplo, dentro da "turma", do círculo de mesma idade, com quem ele ou ela normalmente está. Através disso, da referência mútua sucessiva que os indivíduos tomam, constrói-se um contexto comunicativo, através do qual a apreensão de sentido de cada expressão individual se torna mais clara. E também frente a qualquer um com quem os indivíduos estejam juntos em seu dia a dia sáo utilizados os símbolos, a linguagem e acima de tudo também as metáforas e as imagens que são típicas desse respectivo ambiente. ${ }^{18}$

A análise de imagens - o foco deste texto — através do método documentário segue o mesmo modelo. A busca pelo contexto de produção da imagem é o que dá sentido ao processo, o qual permite a aproximação entre a representação da imagem e a apreensão de seu sentido. A interpretação documentária de imagens segue a mesma lógica metodológica até aqui apresentada, somada ainda a algumas especificidades próprias da natureza da fonte em questáo.

${ }^{18}$ BOHNSACK, Ralf. Rekonstruktive Sozialforschung, op. cit., p. 21. Trad. livre do autor. 


\section{A análise documentária de imagens}

Seguindo a lógica inerente ao método documentário, dois olhares podem ser empregados em relação às fontes imagéticas: pode ser buscado um entendimento sobre (über) a imagem e/ou um entendimento através (durch) da imagem. ${ }^{19}$

Panofsky já seguia essa direção com a diferenciação dos conceitos de iconografia e iconologia. Esses dois conceitos do campo da História da Arte podem ser tomados como análogos aos dois campos de análise inerentes ao método documentário, i.e., a iconografia corresponderia à questão do "o que" (Was-Frage) ou à análise formulada, enquanto a iconologia representaria a questão documentária do "como" (Wie-Frage) ou análise refletida. Na realidade, o método de Panofsky é formado de três fases de interpretação que acabam por englobar, em grande parte, as duas questóes estabelecidas por Bohnsack. A primeira fase, chamada pré-iconográfica, seria dedicada aos elementos primários e naturais da imagem, ou seja, àquilo que possa ser apreendido da composição que seja reconhecido através das experiências e conhecimentos cotidianos. Aqui o pesquisador descreve e avalia em um primeiro momento, também denominado pré-iconográfico, as cores, linhas e os elementos representados, como animais, paisagem, gestos, mímicas e expressóes corporais. Busca-se, portanto, o sentido objetivo da imagem.

Num segundo momento, após a interpretação pré-iconográfica, a busca deve se centrar na totalidade dos elementos anteriormente descritos e na sua apreensão enquanto conjunto, ou seja, em seu significado como tema ou alegoria. A imagem de uma mulher com uma maçã na mão, por exemplo, deve ser aqui reconhecida como uma representação de "Eva". Cenas mitológicas são o exemplo clássico aqui. Trata-se de elementos do imaginário, de imagens preconcebidas e intrínsecas de um grupo ou sociedade. Também os significados "comunicativo-generalizantes" ${ }^{20}$ devem ser aqui descritos, i.e., as interpretaçôes simples dos gestos e das açóes que são representados na imagem.

Para identificar as açóes eu preciso supor um motivo, na verdade um "motivo-para" (Um-zuMotive). Um movimento de "tirar o chapéu" descrito no nível pré-iconográfico é interpretado no nível iconográfico como um cumprimento (...). O meu conhecido tira o chapéu para me cumprimentar. ${ }^{21}$

Também fazem parte do nível iconográfico as análises de estilo e de tipo (Stil- und Typengeschichte). O conceito de "estilo" tem, segundo Mannheim, um duplo-significado. Ele

\footnotetext{
${ }^{19}$ BOHNSACK, Ralf. Qualitative Bild-und Videointerpretation. Opladen: Budrich, 2009, p. 28. Trad. livre do autor.

${ }^{20}$ Ibidem, p. 56.

${ }^{21}$ Idem.
} 
pode designar uma linha estética ou uma escola de arte e desta forma "corresponde a uma mentalidade imanente frente à obra de arte. 'Estilo' designa então: uma em muitas obras pertencentes à mesma linha surgida e reconhecível de um momento composicional." 22 Mas é também um conceito que pode ser delimitado temporalmente, fazendo referência a um "estilo de vida" ou ainda a um "estilo de época" ou "moda". O reconhecimento do estilo pode ser decisivo para o reconhecimento do período relativo ao grupo produtor e/ou retratado na imagem, bem como do sentido a ela vinculado. Já a análise de "tipo" está relacionada com o estudo de uma determinada representação contida na imagem. Isso pode se referir a uma raça, nacionalidade, religiáo ou um determinado personagem, como o diabo ou Zeus. A análise histórica desses elementos permite ao pesquisador o estabelecimento de questôes sobre as qualidades inerentes a eles. Uma representação de Germânia, por exemplo, carrega consigo uma série de ideias cujas origens remetem aos séculos XVIII e XIX, como o nacionalismo alemão, a busca pela unificação dos estados alemães e mesmo o ideal do pangermanismo. Trata-se aqui do sentido expressivo, ou seja, do que a imagem representa por si só (e não necessariamente do que ela é).

O último passo do método de Panofsky é a iconologia, ou seja, a interpretação da imagem através do estudo de sua especificidade como fonte histórica e social.

(...) (o teor da fonte) é compreendido onde se determina o princípio fundamental, o qual revela a mentalidade base de uma nação, de uma época, de uma classe, de uma convicção religiosa ou filosófica, modificada através de uma personalidade e condensada em uma obra. ${ }^{23}$

Tal "princípio fundamental" pode ser reconhecido através da análise da visão de mundo e do habitus da referida sociedade ou grupo, bem como através das imagens que transparecem do seu imaginário e da forma como essas estruturas interagem na composição da fonte. O sentido documentário inerente à imagem é assim revelado.

O método documentário engloba ainda o método "icônico", desenvolvido por Max Imdahl. O historiador da arte alemão concentra seus esforços na caracterização de elementos técnicos da imagem, como, por exemplo, o papel das cores, das linhas, da luz e das formas.

(...) diferentemente da interpretação iconológica de Panofsky, a interpretaçẫo icônica tem início já no plano pré-iconográfico e principalmente na composição formal da imagem. A interpretação icônica pode — de acordo com Imdahl — manter-se em grande parte separada do conhecimento iconográfico prévio, isto é, da atribuição de sentido iconográfica. ${ }^{24}$

\footnotetext{
${ }^{22}$ MANNHEIM, Karl. Strukturen des Denkens, op. cit., p. 95. Trad. livre do autor.

${ }^{23}$ PANOFSKY, Erwin. Ikonographie \& Ikonologie. Colônia: Dumont, 2006, p. 39. Trad. livre do autor.

${ }^{24}$ BOHNSACK, Ralf. Qualitative Bild-und Videointerpretation, op. cit., p. 161. Trad. livre do autor.
} 
Através do método "icônico-iconológico", a análise busca o entendimento da imagem por ela mesma, ou seja, enquanto sistema autodeterminante. A questâo do "como" a imagem é construída e se expressa em sua determinação contextual, ou seja, em sua dimensão histórica, é evidenciada e respondida no método icônico através do olhar sobre seus elementos técnicos constituintes.

O método icônico é uma metodologia de descrição de fenômenos, a qual - isso deve ser apontado - tem por base um conceito de forma e de imagem diferente daquele dos métodos iconográfico e iconológico. Ele dedica-se à síntese do "olhar que olha" e do "olhar que reconhece" enquanto fundação de uma apreensão de sentido bastante específica e ainda informulável e investiga como semântica e síntese influenciam na imagem. ${ }^{25}$

Algumas imagens, como as charges ou quadrinhos, contêm ainda elementos textuais em sua composição. Apesar de muitos chargistas trabalharem somente com imagens, uma grande parte utiliza o artifício textual para complementar a mensagem do conjunto, seja através de uma legenda ou de um diálogo. A análise desses elementos deve ser realizada após a interpretação do conteúdo imagético, mas deve ser efetuada em acordo com tal conteúdo. Os textos podem dar um significado totalmente diverso ao dado pela simples interpretação da imagem. Através de uma legenda ou de um diálogo na cena a mensagem pode sofrer uma modificação visceral. Isso ocorre, por exemplo, na utilização de um humor irônico através da confrontação das duas mensagens, a pictórica e a textual. Uma imagem "normal", que não causaria qualquer reação do observador, pode repentinamente mostrar uma nova faceta - uma crítica à determinada linha de pensamento ou personalidade política, por exemplo - e através disso mudar a percepção do leitor quanto à imagem e, talvez, ao próprio objeto retratado.

Os elementos textuais nas charges, entretanto, se diferenciam dos textos que encontramos em cartoons ou em quadrinhos. Este último tipo de arte visual, em especial, se utiliza normalmente de mais de um espaço de representação, isto é, apresenta uma natureza sequencial e, portanto, tem mais espaço para desenvolver a mensagem do que as charges. Estas, por sua vez, têm apenas um "quadro" para desenvolvê-la — têm seu início, meio e fim em um mesmo espaço - e por isso mesmo têm de proporcionar uma compreensão imediata. Por esta razão, a mensagem da charge por vezes depende da frase derradeira, de um título ou de uma legenda, elementos que se aliam às expressóes corporais e expressivas dos personagens representados para conseguir alcançar o efeito desejado. ${ }^{26}$ No caso específico das charges, existem ainda exemplos que são dependentes de textos jornalísticos apresentados normalmente na mesma edição do periódico, seja ele um jornal ou uma revista. Cabe então

\footnotetext{
${ }^{25}$ IMDAHL, M. Gioto — Arenafresken. Ikonographie — Ikonologie — Ikonik. Munique: Fink, 1988, p. 99. Trad. livre do autor.

${ }^{26}$ EISNER, Will. Quadrinhos e arte sequencial. São Paulo: Martins Fontes, 1995.
} 
ao pesquisador julgar a relevância ou a necessidade da análise do referido texto, se ambos devem ser tomados em conjunto ou se a charge deve ser tomada como fonte primária e a notícia como fonte secundária, servindo de apoio interpretativo. Os elementos textuais devem confrontar, apoiar ou comprovar a análise iconológica, ou seja, devem ser relacionados com esta etapa da análise, pois se referem diretamente ao espaço de pensamento do artista, sua visão de mundo, podendo trazer ao mesmo tempo informaçôes sobre o lugar, o campo e o ambiente político, ou ao período no qual o desenhista se encontra, determinando, por fim, o sentido último da mensagem.

\section{Produtores de imagens retratadores e retratados}

A posição dos produtores da imagem, tanto no campo físico quanto no temporal, tem relevância capital para a análise documentária de imagens. Esse reconhecimento é necessário e precisa ser constantemente discutido, pois, à primeira vista, duas formas de produção podem ser percebidas: a produção "objetiva" e a "subjetiva".

Na produção objetiva o autor se utiliza de modelos reais, como nos casos de fotografias e de retratos. O modelo está presente no mesmo ambiente do autor e há uma interação real entre os dois produtores, os quais Bohnsack ${ }^{27}$ identifica como produtor ativo ou produtor que representa (abbildender Bildproduzent) e o produtor retratado (abgebildeter Bildproduzent), retirando qualquer ideia de passividade na definição de seus papéis. Isso porque o produto final é o resultado de uma equação que engloba habitus, Weltanschauung e mesmo o imaginário de ambos, os quais não são necessariamente idênticos. Tais elementos, que foram aqui discutidos no campo teórico, encontram-se por fim na representação: um retrato renascentista ou uma foto contemporânea são representaçôes do habitus do produtor retratado, suas disposiçôes de ação e de reação de determinada forma, mas carregam também as disposiçôes mentais e práticas do produtor retratador da imagem, tanto no que se refere ao posicionamento deste em relação ao primeiro quanto suas escolhas de estilo e formas de produção, as condiçôes técnicas a que se submete etc.

A produção subjetiva, por sua vez, segue o mesmo modelo de análise, mas aqui o papel do produtor retratado precisa ser tomado de modo diferenciado, pois este não está presente no momento de produção e não toma parte ativa da mesma. Isso significa que o artista/produtor retratador trabalha com base em uma imagem "virtual" do retratado e em uma concepção unilateral idealizada das estruturas mentais e praxiológicas que cercam o retratado - não há uma interação direta entre os dois produtores, mas uma interpretação do produtor retratado através da ação do retratador. Na produção subjetiva impera a criatividade e a visão de mundo deste, pois o retratado pode mesmo sequer existir, pode ser um personagem imaginário ou ain-

\footnotetext{
${ }^{27}$ BOHNSACK, Ralf. Qualitative Bild-und Videointerpretation, op. cit..
} 
da uma representação de uma personalidade ou grupo existente. O ponto central neste caso é que a imagem é, de maneira muito mais determinante que na produção objetiva, um ponto de vista pessoal do artista/retratador, e que, portanto, as características apresentadas do retratado são, da mesma forma, baseadas nas impressóes/ideias do produtor retratador.

Este é exatamente o caso quando se trata de imagens como as charges. O chargista toma uma personalidade ou um fato relevante social e politicamente e o apresenta a partir de seu próprio olhar. Através de uma representação pictórica, muitas vezes acompanhada de humor, o desenhista pode desenvolver um elogio ou uma crítica. $\mathrm{O}$ trabalho do chargista pode ser visto ainda como um exercício misto de representação subjetiva e objetiva, pois o objeto ou personagem representado normalmente existe na sua realidade e a sua crítica é direcionada ao seu próprio tempo e espaço. A charge é também, entretanto, uma representação da visão pessoal do desenhista, um produto de suas próprias motivações, mostrando uma imagem distinta do produtor retratado, concebida e formatada pelo produtor retratador. É nas subjetividades do retratador que podemos encontrar a própria essência do retratado no ambiente fechado da imagem.

A natureza política das charges permite que seu estudo revele nuances e detalhes das visóes políticas e ideológicas intrínsecas ao grupo ao qual o artista pertence. ${ }^{28}$ Aqui, o que poderia ser tomado como propaganda ou defesa de um determinado ponto ideológico nada mais é do que a consubstanciação da visão de mundo com o próprio ofício do chargista. As estruturas mentais do grupo em questão (em especial no que concerne aos posicionamentos políticos) se revelam assim nos desenhos, que podem ainda trazer indícios das estruturas práticas, ou seja, do habitus, uma vez que a própria produção da charge pode ser tomada como uma manifestaçáo do mesmo.

O habitus é refletido ainda no elemento humorístico e/ou violento que estão presentes na grande maioria das charges. A própria utilização do humor na constituição da charge é um exemplo da relação entre o habitus inerente ao grupo do produtor retratador da imagem e o humor, podendo aqui ser verificado o estilo, o tipo e a forma de humor que é costumeiramente utilizado entre os membros do grupo, que tipo de humor "funciona" entre eles. $\mathrm{O}$ humor carrega consigo ainda sinais da cultura do grupo e apresenta as ideias corriqueiras ou tidas como normais, bem como preconceitos e códigos culturais da sociedade em questão. $\mathrm{O}$ produtor retratador, membro deste grupo, reproduz os elementos mentais na charge, $\mathrm{e}$

\footnotetext{
${ }^{28}$ Em um aspecto mais amplo, também do grupo do qual o veículo onde as charges são publicadas é representativo, seja ele jornal, revista ou site na internet. Aqui as concepçóes e visôes de mundo se confundem, a liberdade do chargista, assim como dos jornalistas, é mesclada com a "linha editorial" defendida pelo jornal sem que isso seja tomado como uma afronta ou imposiçáo pelos profissionais. Antes, ocorre uma padronizaçáo de opinióes e visóes de mundo de empregado e empregador, que passam a poder ser defendidas nas matérias e nas charges com ética e afinco (ACCARDO, Alain et al. Journalistes au quotidien - Outils pour une socioanalyse des pratiques journalistes. Bordeaux: Le Mascaret, 1995; e ACCARDO, Alain. A estranha ética dos jornalistas. Le Monde Diplomatique, jan. 2003. Disponível em: <http://www.diplo.com.br/aberto/0005/24. htm>. Acesso em: 12 fev. 2003).
} 
o resultado é um exemplo do modus operandis do grupo, das estruturas práticas e mentais dessa coletividade.

A mesma linha de raciocínio pode ser empregada para a presença de violência nas imagens. As representaçóes violentas podem também ser tomadas como produtos dessas estruturas e mostram exemplos de ideias e açôes tidas como comuns ou conceptíveis pelo grupo. Trata-se de imagens contra alguém ou alguma coisa e que ainda podem trazer consigo o elemento humorístico, como, por exemplo, em representaçóes de alguém como Satá ou um ataque a um grupo específico. Além disso, o humor pode ser utilizado como uma forma de violência, seja na ironia contra o alvo da pilhéria ou na diminuição de seu status ou condição social no sentido apontado por Bergson. ${ }^{29}$

Essa estrutura analítica, bem como os questionamentos proporcionados pelo método documentário, permite ao pesquisador um olhar abrangente sobre o tema analisado ao mesmo tempo que leva em consideração as especificidades e potencialidades da fonte pictórica. As estruturas e os elementos práticos e mentais envoltos às fontes podem ser analisados qualitativamente, em separado e em conjuto. $\mathrm{O}$ emprego do método e a caracterização de cada etapa da interpretação poderão ser mais bem visualizados no exemplo de análise a seguir: ${ }^{30}$

Figura 1 - FIPS. Angst. Der Stürmer, no. 7. feb. 1935. p. 6.

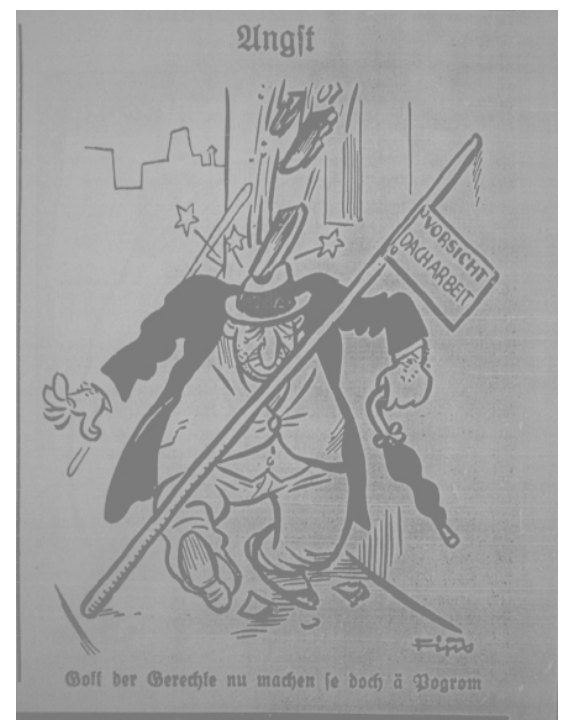

${ }^{29}$ BERGSON, Henri. O riso. São Paulo: Martins Fontes, 2001.

${ }^{30}$ A prática do método documentário não prescinde de uma análise comparativa entre as fontes, o que resultará na sua validação enquanto método de estudo de contextos e de grupos sociais historicamente situados. Entretanto, por questóes de espaço e de objetividade, será apresentado aqui apenas um exemplo de análise, ou melhor, de reconstrução de uma charge. Para uma visualização do método em sua condição global, com suas implicaçôes analíticas sociogenéticas e de construçôes de sentidos, ver LIEBEL, Vinícius. Politische Karikaturen und die Grenzen des Humors und der Gewalt. Opladen: Budrich Unipress, 2011. 
Datada de fevereiro de 1935, a charge acima, intitulada "Medo" (Angst), foi publicada no jornal Der Stürmer, fundado em Nuremberg no ano de 1923. O jornal teve sua linha pautada desde sua fundação pelo antissemitismo, assumindo grande importância na ascensão e consolidação do Partido Nazista e na disseminação do elemento antissemita em seu ideário. Inicialmente com um alcance apenas regional, limitado às áreas próximas de sua cidade natal, o jornal vivenciou uma progressiva e contínua evolução no seu volume de vendas. Até 1933, ano da chegada de Hitler ao poder na Alemanha, o Stürmer já contava com uma circulaçáo que englobava todo o estado da Bavária (a tiragem de 1933 era de aproximadamente 25 mil exemplares por semana).

A partir de entâo, aproveitando-se da influência que a máquina de poder nazista lhe proporcionava, tornou-se um jornal de circulação nacional. O crescimento de seu alcance foi acompanhado por um aumento estrondoso de sua tiragem: no ano de 1938 o número de exemplares impressos por semana já era de 470.000 e, até o final do período nazista, esse número ultrapassou a linha do milhão e meio de exemplares distribuídos. ${ }^{31} \mathrm{O}$ Stürmer foi publicado durante 22 anos sob o mote "os judeus são nossa desgraça" (frase impressa na primeira página de todas as ediçóes) e sobreviveu às conturbadas mudanças na estrutura política e econômica da Alemanha das décadas de 1920 a 1940. O estilo do jornal pode ser classificado como "popular", ou seja, era voltado às camadas menos privilegiadas da população, especialmente aos trabalhadores: pequenos artigos e um grande número de ilustraçôes compunham as páginas do semanário, além da linguagem direta e plena de violência. A ideologia e a visão de mundo nacional-socialistas, o núcleo duro da linha editorial, tinham no judeu seu principal bode expiatório. Todo problema social e econômico na Alemanha era respondido e relacionado com a "questão judaica", e isso era refletido nas páginas do semanário. As formas de representação do elemento judeu nas charges eram variadas, assim como os temas nelas abordados. O horror, elo que unia as representaçóes e os textos do jornal, podia andar de máos dadas com o humor para atingir o alvo das críticas, que muitas vezes eram dirigidas a múltiplas instituiçôes e grupos sociais, sem que com isso perdessem a invariabilidade do judeu como seu ponto central.

\footnotetext{
${ }^{31} \mathrm{O}$ número máximo de 1 milhão e meio de exemplares vendidos é fornecido por Streicher, o fundador e editor do jornal, em suas entrevistas durante o processo de Nuremberg (GOLDENSOHN, Leon. The Nuremberg Interviews. Londres: Pimlico, 2007, p. 252-263) e se refere, provavelmente, às ediçóes especiais do semanário por ocasião dos encontros nacionais do partido, onde o jornal era distribuído gratuitamente em grande quantidade. A média de exemplares distribuídos após 1935, entretanto, gira em torno dos 700.000 (BYTWERK, Randall L. Julius Streicher - Nazi Editor of the notorious anti-semitic newspaper Der Stürmer. Nova York: Cooper Square, 2001, p. 57).
} 


\section{Elementos pré-iconográficos}

Em primeiro plano, um homem de chapéu pode ser observado andando em uma rua. Ele também veste terno e um sobretudo, segurando um guarda-chuva na mão esquerda. Ele anda ao lado de um prédio, do qual é possível ver uma janela. À frente do homem um bastâo está posicionado na vertical e tem uma pequena placa na extremidade superior. $\mathrm{O}$ posicionamento do bastáo produz um corte transversal na figura central, dividindo seu corpo na altura do peito, passando pela perna direita e seu ombro esquerdo. Um outro bastão se encontra no plano de fundo, localizado paralelamente ao primeiro e também encostado junto ao prédio. Três objetos caem sobre a cabeça do homem e no chão podem ser vistos alguns pedaços do mesmo material. No plano de fundo podem ser vistos ainda os contornos de outros prédios.

O personagem tem a barba malfeita e "orelhas de abano", bem como um nariz grande e "pés chatos". As costas das mãos apresentam pelos e a expressão corporal geral (com os ombros erguidos, pescoço arqueado e cabeça abaixada) denota surpresa e/ou medo. O homem é gordo, o que pode ser notado pelas roupas justas. A expressão do rosto, da mesma forma que a corporal, denota medo ou dor, o que pode ser reconhecido através dos "elementos instáveis", 32 como os olhos e a boca. Os olhos estáo fechados e os cantos da boca direcionados para baixo, compondo o conjunto expressivo do rosto.

\section{Análise iconográfica}

O personagem central pode ser reconhecido como um judeu, o que é denunciado pelo tipo de representação (Typengeschichte). Elementos da forma desempenham papel determinante na significação da charge/caricatura aqui apresentada, no caso, especialmente o nariz aponta para tal reconhecimento.

A caracterização do judeu desta maneira não é um fenômeno moderno ou uma invenção dos antissemitas do século XX. Trata-se de uma representação que remete à Idade Média, mas que foi largamente difundida apenas após a invenção da imprensa, no século XV. Torna-se um "fenômeno de massas" apenas no século XIX, quando as imagens passaram a ilustrar livros e cartóes-postais. ${ }^{33} \mathrm{~A}$ caracterização física dos judeus em tais ilustraçôes mostra uma constante concentração em alguns elementos estáveis que apontam para a estigmatização. $\mathrm{O}$ "nariz judeu" passa então a ser sempre representado na forma de um seis, o que não apenas

\footnotetext{
${ }^{32}$ GOMBRICH, Ernest Hans. Kunst \& Illusion - Zur Psychologie der bildlichen Darstellung. Berlim: Phaidon, 2004.

${ }_{33}$ SILVAIN, Gérard; KOTEK, Joël. La Carte Postale Antisémite. De l'affaire Dreyfus à la Shoah. Paris: Berg International, 2005.
} 
identifica os personagens como judeus, mas também carrega consigo todos os preconceitos e as características distintivas imputadas a esse grupo.

(...) a relação do nariz como marca de diferenciação em contraste com outros e o nariz como garantia, como marca de um judeu "real" - isso faz do nariz antissemita um significante. Como tal ele é integrado em uma "eternidade atemporal", na qual ele é feito sujeito de uma frase que diz: "o judeu É..." o judeu (...) é um significado produzido pelo significante "nariz". ${ }^{34}$

O nariz da figura é, portanto, a marca central para sua identificação. É ao seu redor que será construído o enquadramento de valores e de características morais que demarcarão negativamente o seu portador. Ao nariz somam-se ainda as orelhas "de abano", que compóem também o rosto judeu "típico" e os "pés chatos". Tais elementos pictóricos constituintes e "estáveis" desempenham um papel estigmatizador e identificador, que servirão, na lógica que segue tais representaçóes, de definiçâo de toda a natureza do retratado. Seu caráter iconográfico é assegurado por seu estudo tipológico, o que coloca essa representação em uma relação estrutural quando situada em seu contexto de produção. Não sendo um produto exclusivo do período nazista, mas se tornando dele típico por uma característica culturalmente construída, como resultado de um habitus antissemita de múltiplos matizes, a representação do judeu nesses termos se mostra antes um elemento iconográfico. Nesse sentido, tais elementos, constantemente utilizados na representação dos judeus, tornariam-se da mesma forma portadores da "judeidade", daquilo que caracterizaria o judeu (e assim estariam aptos a carregar consigo também os sentimentos e reaçóes a ela). Esse quadro global relativo ao judeu aqui representado apresenta antes uma natureza arquetípica antissemita que conjuntural nazista.

Uma segunda caracterização proveniente da forma é observada através da vestimenta representada. Após o reconhecimento da figura central como um judeu, a identificação do vestuário que ele porta cresce em importância. A partir do terno (justo) e do sobretudo, é possível concluir que não se trata de um indivíduo pobre, nem mesmo de um operário. $\mathrm{Na}$ realidade, ele está mais próximo de ser um petit-bourgeois: o terno o coloca na posiçáo de funcionário público ou, mais provavelmente, de homem de negócios, mas ao mesmo tempo aponta para um sucesso relativo, não se tratando de um banqueiro ou de um milionário. Trata-se, ainda assim, de um capitalista.

A imagem do "judeu capitalista" revela uma dimensão do preconceito construído sobre esse grupo. Esse preconceito tem suas bases na suposta relação intimista entre judeus e dinheiro, gerando e adicionando atributos, como a cobiça e a avareza. Essas imagens estão presentes

\footnotetext{
${ }^{34}$ CHARIM, I. Der negative Fetisch — Zur Funktionsweise rassistischer Stereotype. In Jüdisches Museum Berlin. Typisch! Klischees von Juden und Anderen — Katalog der Ausstellung. Berlim/Viena: 2008, p. 27-38. Trad. livre do autor.
} 
desde a Idade Média no imaginário ocidental/europeu e foram constantemente desenvolvidas e reforçadas. A imagem do judeu como negociante e usurário acompanha o judeu desde entáo e tomou proporçóes ainda maiores com o surgimento dos estados nacionais modernos, quando os judeus foram empregados nos serviços públicos e burocráticos. ${ }^{35}$ Neste ponto é moldada a imagem que servirá de base para o antissemitismo moderno. Sua presença no imaginário ocidental não influenciou apenas a imagem dos judeus no olhar dos não judeus, mas também a imagem dos não judeus aos seus próprios olhos através da contraposição de conceitos como honestidade e desonestidade, avareza e generosidade, bondade e maldade. A produção dessas fronteiras imaginárias pode ser automaticamente retomadas assim que um leitor não judeu tem contato com uma imagem como a exposta acima. Tal caracterização raramente surge sozinha, pois a imagem já está formada no imaginário e, dessa forma, pode ser constantemente "acionada" com propósitos diversos, sejam eles políticos ou religiosos.

Pode-se ainda observar que a cena apresentada na imagem se passa em um ambiente urbano. O plano de fundo na forma de prédios compóe o cenário juntamente da construção que domina o lado direito da figura. Além disso, a área onde o personagem central se encontra é demarcada e delimitada, podendo ser identificada através dos dizeres da placa: "reforma de telhado" (Dacharbeit). A queda dos três objetos (que agora podem ser identificados como telhas) sobre a cabeça do pedestre pode ser presumida um acidente de trabalho.

\section{Composição formal}

Quando se analisa a composição formal de uma charge é preciso confrontar alguns problemas de ordem técnica, especialmente graças à natureza grotesca e caótica que esse tipo de desenho tende a apresentar. Normalmente o artista não a desenha seguindo regras formais, mas lança mão da desproporcionalidade na composição.

Na Figura 2 a composição planimétrica da charge pode ser observada, partindo da linha que demarca o canto do prédio da direita em sincronia com as linhas que contornam a calçada (linhas inteiras). Essa demarcação coloca em evidência a calçada, que é o "palco" da cena, onde os principais elementos da imagem estão colocados: o judeu e o bastáo com a placa de aviso. A posição deste em relação à calçada pode ser observada através das linhas tracejadas projetadas a partir da ponta do bastão, acompanhando a parede do prédio em linha reta até a calçada, seguindo entâo até a extremidade inferior do bastão e formando com este um triângulo reto. A partir dessa projeção, tem-se a impressão de que o joelho direito do personagem está batendo contra o bastão. As linhas pontilhadas seguem as coordenadas dadas pela janela do prédio e as marcas da parede, proporcionando uma coordenada espacial para o desenvolvimento da ação.

\footnotetext{
${ }^{35}$ ARENDT, Hannah. Origens do totalitarismo. São Paulo: Companhia das Letras, 2000.
} 


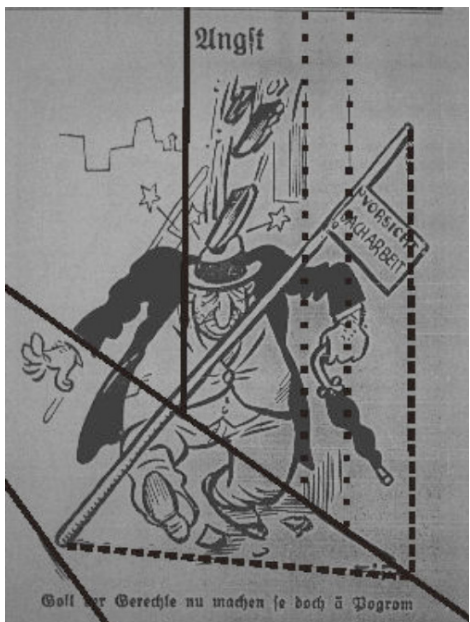

Figura 2

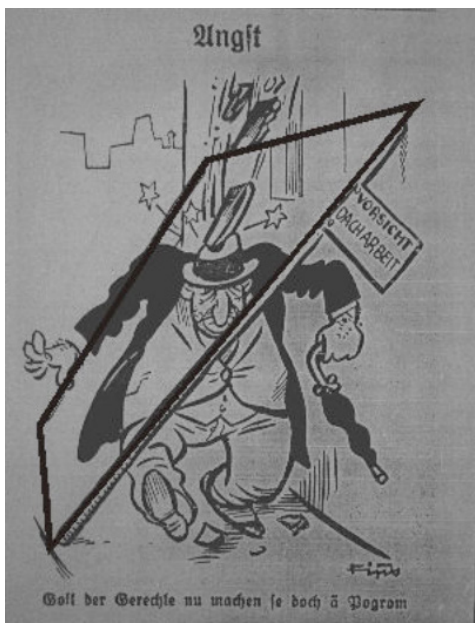

Figura 3

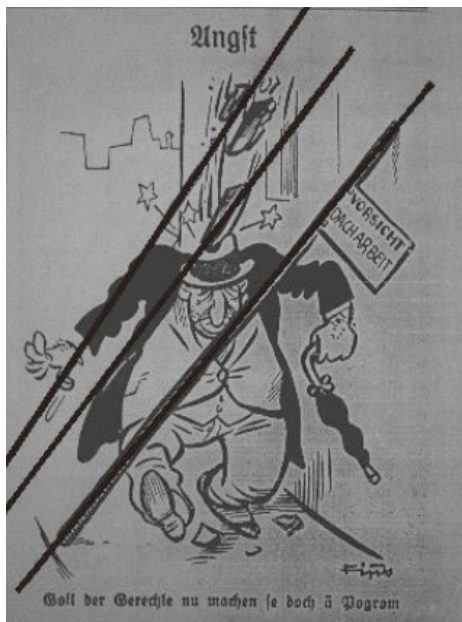

Figura 4

Na Figura 3 observa-se a delimitação do "campo de obras" onde a reforma do telhado é feita. Essa área se encontra entre os dois bastóes e abrange a área da calçada onde se encontra o personagem. O paralelogramo delimita assim o campo onde a cena se passa e os elementos principais se encontram. Já a Figura 4 mostra três linhas traçadas em aproximadamente $45^{\circ}$ que seguem a direção dos dois bastóes e da borda da telha que toca a cabeça do passante. Esse conjunto de linhas parece pressionar o judeu contra a parede do prédio.

\section{Interpretaçóes icônico-iconológica}

A figura do judeu no centro da imagem é apresentada caminhando em uma calçada de uma cidade (alemâ?). No primeiro plano pode-se observar uma placa que alerta: "Cuidado - Reforma de telhado" (Achtung - Dacharbeit). Enquanto o judeu anda pela área marcada, algumas telhas caem na sua cabeça, causando aparente dor e medo no personagem.

O que é retratado na charge é uma cena que poderia ocorrer em qualquer cidade parece tratar-se de um acidente, e nem mesmo as três telhas que caem sobre a cabeça do judeu comprovariam que se trata de um ataque. Esta possibilidade, entretanto, não pode ser deixada de lado. De qualquer forma, o foco da imagem recai sobre a área que a Figura 3 explicita. O personagem, apesar das advertências contidas nas placas, entra neste campo e, em consequência de sua ação, acaba sofrendo o "acidente". Sua insistência em atravessar esse perímetro a despeito das advertências pode ser tomada como um sinal de estupidez, pois ele persiste nessa opçáo quando poderia atravessar a rua, desviar da área demarcada ou mesmo tomar outra direção: ele sofre as consequências por escolher seguir aquele caminho. A ideia da estupidez pode ser contrastada ainda com a do maquiavelismo: o judeu atravessaria a área justamente por saber que sofreria com isso. Ele o faria, assim, para cha- 
mar a atenção de todos para sua posição de agredido, buscando talvez a manipulação da opinião pública a seu favor.

A área demarcada pode ser entendida aqui como uma analogia: apesar de todos os avisos e advertências, o judeu continua a trilhar seu caminho (na Alemanha) e em tal região alguns "acidentes" podem acontecer, visto que uma "reforma" está acontecendo ali. O judeu segue seu caminho sob sua própria conta e risco. Esta mensagem está de acordo com a visão de mundo (Weltanschaunng) do grupo no poder naquele momento, qual seja, o grupo nacional-socialista. Na realidade, a partir de 1935 (ano de publicação da imagem) ocorre uma intensificação da pressão contra os judeus na Alemanha, acusando uma crescente mudança no habitus dominante motivada, principalmente, pelo fortalecimento do antissemitismo no discurso nazista. Sob a liderança de Julius Streicher, a Questão Judaica (Judenfrage) passa a ser disseminada com mais força e frequência. As primeiras açóes do novo governo alemão contra os judeus são empreendidas durante o natal de 1934 com uma intensidade crescente:

O primeiro alvo das mobilizaçóes antissemitas eram as lojas de judeus: as entradas eram bloqueadas, clientes eram fotografados, vitrines tinham cartazes colados ou eram quebradas, protestos eram promovidos na frente dos estabelecimentos ou das casas dos proprietários. Além disso, judeus eram atacados especialmente por seus relacionamentos íntimos com não judeus, sendo acusados de "detratores da raça". Nas piscinas públicas foram organizados incidentes que frequentemente acabavam com o banimento dos judeus, e ativistas do partido pressionavam para que placas de aviso fossem afixadas nas entradas de estabecimentos para declarar que aquele lugar era "livre de judeus". ${ }^{36}$

A imagem desempenha assim um papel duplo: não se trata apenas de uma advertência aos perigos aos quais os judeus estariam expostos ao viver na Alemanha ou mesmo de uma ameaça contra eles; a charge pode ser interpretada também como um chamado à ação contra os judeus. A queda das telhas seria entáo apenas mais um exemplo da onda de violência, um exemplo que objetivaria a declaraçâo da área assinalada na Figura 3 uma área livre de judeus. Nesse sentido, a imagem seria utilizada como simples propaganda e o judeu ali representado como um simbolismo para todo o povo judeu, povo que carregaria consigo todos os "estigmas raciais" ali representados. A violência contra o judeu na imagem seria a representação de uma ação contra toda sua raça e seus vícios, os quais estariam manchando o povo alemão.

A presença de três telhas (além dos pedaços que já se encontram no chão) pode também ser tomada como uma alegoria da unidade do povo alemáo (ou ao menos dos nazistas) no seu "trabalho conjunto" contra os judeus. Este sentido de unidade é também parte importante da visão de mundo dos nacional-socialistas e está intimamente ligada ao conceito de

\footnotetext{
${ }^{36}$ LONGERICH, Peter. "Davon haben wir nichts gewustt!" - Die Deutschen und die Judenverfolgung 19331945. Munique: Pantheon, 2007, p. 75. Trad. livre do autor.
} 
Volksgemeinschaft. Tal conceito foi extensivamente utilizado no período em questão (193336), focado na angariação de novos adeptos e partidários. Segundo Hannah Arendt, ${ }^{37}$ a fase do movimento nazista (1922-33) seria dedicada ao arrebanhamento de "verdadeiros" nazistas, i.e., de membros que acreditavam e compartilhavam da visão de mundo defendida pelo partido. A grande maioria dos nacional-socialistas do alto escaláo ligou-se ao NSDAP ainda nesta fase, o que é salientado pelo sistema organizacional e administrativo em forma de cebola adotado pelos nazistas (com Hitler ao centro da estrutra). O fanatismo e o compromisso com o partido e a ideologia podiam determinar o posicionamento do indivíduo na estrutura de poder, mas não eram condiçôes determinantes na sua inserção na Volksgemeinschaft. Para tanto somente a condição racial era observada, o que excluía obviamente os judeus.

Também a caracterização "semianimalesca" se mostra aqui elemento determinante. A presença de pelos no corpo do judeu poderia ser entendida como uma comprovaçáo de sua inferioridade, de sua proximidade biológica e evolutiva com animais ou mesmo de sua condição sub-humana (Untermenschenbedingung). Evidencia-se aqui a tentativa de animalização do judeu através da presença dos pelos nas máos e da barba malfeita no rosto. Tais elementos, para além de uma "incivilidade", denotam uma aproximaçáo do judeu com os animais, uma relação que remete à questáo evolutiva. ${ }^{38} \mathrm{~A}$ ideia da superioridade de algumas "raças" (notadamente a ariana) é apresentada aqui en passant. A violência contra o judeu mostrada na charge seria o agente praxiológico de caracterização e diferenciação dos integrantes e dos não integrantes desta coletividade, um elemento que agiria para estreitamento da identidade dos membros da Volksgemeinschaft, apresentando a composição fechada de uma amostra de seu habitus.

\section{Análise dos elementos textuais}

A partir da leitura do título "Medo" (Angst) e da legenda "Deus justo, eles estáo fazendo um Pogrom" (Gott der Gerechte nu machen se doch ä Pogrom) abre-se uma nova direção para a interpretação da imagem e a análise de sua composição geral.

\footnotetext{
${ }^{37}$ ARENDT, Hannah. Origens do totalitarismo, op. cit.

${ }^{38}$ Tal constatação é possível a partir da comparaçáo desta e de outras imagens representativas de judeus no contexto analisado com as imagens que representavam os alemães arianos. Estes eram inevitavelmente representados de barba feita, sem pelos aparentes e de espinha ereta. Os judeus, como evidenciado em outras análises (LIEBEL, Vinícius. Politische Karikaturen und die Grenzen des Humors und der Gewalt, op. cit.), tendem a ser representados com características flagrantemente símias, com pelos aparentes (especialmente nos braços e no peito) e com postura levemente curvada, muitas vezes com uma pronunciada corcunda (o que poderia ainda denotar um físico torto, condizente com a suposta moral deturpada a eles imputada pelos antissemitas). Essa representação ganha impulso com a grande disseminação das ideias darwinistas ainda no século XIX, o que propicia a aproximaçáo da teoria darwinista da evolução com a corrente do darwinismo social.
} 
O primeiro elemento a ser analisado aqui é a linguagem exposta na legenda, que promove uma delimitação entre os diferentes grupos sociais da Alemanha naquele momento, marcadamente entre judeus e alemães. Algumas palavras são grafadas de forma errônea, denunciando uma pronúncia equivocada e a condição de estrangeiro do judeu, de não pertencimento ao referido grupo social. Além disso, a expressão "Deus justo" é uma frase padrão normalmente utilizada nas páginas do Der Stürmer como uma interjeição típica dos judeus, promovendo assim uma espécie de identificação e estigmatização verbal deste grupo.

Uma análise conjunta do título e da legenda mostra uma nova apreensão de sentido para a charge. $\mathrm{O}$ humor desempenha um papel importante para a interpretaçấo da charge e os elementos textuais são o agente denunciador de sua natureza. O título "Medo" mostra a atmosfera reinante no desenho, ou seja, denota o sentimento do personagem central. Da junção dos elementos textuais tem-se o sentido humorístico do desenho, que reside no suposto exagero do judeu. A obtusidade do personagem é também reforçada: os judeus não conseguiriam sequer diferenciar um pogrom de uma reforma — na Alemanha não existiria, portanto, pogrom, mas um trabalho de saneamento. Da mesma forma, a ideia do maquiavelismo pode ser retomada: a exclamaçáo do judeu seria a expressáo de uma falsa vítima, que acusaria a existência de um pogrom inexistente, exagerando a realidade em busca da manipulação - e a representação o denuncia, promovendo a ira contra o judeu.

Este exagero na percepção é o ponto principal da pilhéria: três telhas caem sobre o judeu e este prontamente declara estar diante de um pogrom. Tal exagero pode ser reconhecido como uma alegoria da situação do povo judeu. Cada denúncia ou reclamação dos judeus contra a perseguição que já sofriam em 1934 e 1935, segundo a charge, seria simples exagero. Assim, o tema e o grupo social dos judeus se tornam risíveis, ou seja, menosprezáveis, e a seriedade dos ataques reais passa a ser reduzida. Ao mesmo tempo, a exposição da falsidade e da mentira do judeu visa à perpetuaçáo das hostilidades contra seu grupo, promovendo o riso pela sua insignificância e o ódio pela sua petulância.

\section{Conclusão}

Em meio a uma revalorização das fontes imagéticas e a sua reapreciação documental, as pesquisas historiográficas têm se pautado cada vez mais por seu uso e buscado em suas características próprias as evidências históricas que norteiam suas reflexóes. Esse movimento afirmativo das imagens é ainda mais evidente no que tange às pesquisas em História Política e História Cultural do Político.

A proposta de Mitchell $^{39}$ de percebermos as imagens não apenas como um reflexo de seu ambiente e de sua conjuntura, mas também como formadora desses mesmos ambiente e con-

\footnotetext{
${ }^{39}$ MITCHELL, William John Thomas. Picture Theory, op. cit., p. 11 et seq.
} 
juntura transpassa o caráter simbólico e ilustrativo das imagens e abre um novo campo de análises, um campo no qual a imagem é tomada como um agente político e social. Essa nova perspectiva não elimina nem vai de encontro ao princípio da presentificação da imagem que Warburg e, mais recentemente, Didi-Huberman desenvolvem em suas reflexóes, mas antes o complementa em uma perspectiva temporal específica de sua produção. Enquanto esses estão preocupados com o processo da materialização e continuação da memória e com, nos termos de Warburg, a Nachleben da imagem e do imaginário, ${ }^{40}$ buscando "desenclausurar a imagem e o tempo que ela carrega — ou que a carrega", ${ }^{41}$ o que a perspectiva de Mitchell sugere é uma abordagem de viés sociológico e linguístico, na qual a imagem é pensada em termos não puramente discursivos, mas onde a "relação entre imagem e discurso (seja) entendida, entre outras coisas, como uma relação de poder" ${ }^{42}$

Mas se Mitchell pensa essa relação em termos amplos, sublinhando a força do capital na composição do ambiente visual, a problematização que ele traz tem uma ressonância ainda maior no campo dos estudos políticos. Pensar, como fizemos aqui em um exercício empírico, a iconologia de um determinado regime político, passa a ser um expediente mais complexo, mas infinitamente mais frutífero em sua incursáo no contexto estudado. Ainda, aqueles regimes de caráter totalitário e que visam à formatação de uma religião cívica (o que acarreta invariavelmente em uma iconodulia) se mostram especialmente atraentes para essa abordagem. As imagens nesses contextos, desde charges e cartuns até quadros e estátuas, se moldam a um ideal que, por sua vez, se talha de acordo com a força das imagens. Na falta de um termo que dê conta desse processo, pode-se afirmar com Igor Golomstock que as imagens são parte integrantes e ativas de "processos de um clima social e intelectual”, ${ }^{43}$ ou seja, são criaturas de uma dinâmica cultural específica, mas contribuem para a formatação dessa mesma dinâmica ao expressar e dar uma materialidade visual a ela, alargando o espectro de atuação e de alcance dessa estética.

De fato, a vinculação entre estética e política, para além da mera iconografia, tem sido objeto primordial de atenção dos estudiosos da área. Com vistas a essa relação, Jacques Rancière $^{44}$ cunha a expressão "partilha do sensível", dando conta desse ponto tangencial entre o campo da estética e da política. Para o autor francês, esses dois campos compartilham aquilo que têm de mais básico, mas também de mais específico, que é aquilo que se dá ao sensível (a aparência). Ela carrega consigo um sentido próprio, conjuntural, e ao mesmo tempo comum a toda a sociedade, mas também de certo modo restritivo em sua

\footnotetext{
${ }^{40}$ WARBURG, Aby. Dürer e a Antiguidade italiana. In: WARBURG, Aby. Histórias de fantasmas para gente grande. São Paulo: Companhia das Letras, 2015, p. 87-96.

${ }^{41}$ DIDI-HUBERMAM, Georges. A imagem sobrevivente — história da arte e tempo dos fantasmas segundo Aby Warburg. Rio de Janeiro: Contraponto, 2013, p. 34.

${ }^{42}$ MITCHELL, William John Thomas, op. cit., p. 6.

${ }^{43}$ GOLOMSTOCK, Igor. Totalitarian Art. Nova York: Overlook, 2011, p. 6.

${ }^{44}$ RANCIÈRE, Jacques. A partilha do sensivel. São Paulo: Editora 34, 2009.
} 
representação dos atores autorizados a exercê-la. Aliam-se então a capacidade única das imagens de condensar mensagens e, nas palavras de Gombrich, "de transmitir informaçóes que não podem ser codificadas de nenhuma outra forma", ${ }^{45} \mathrm{com}$ as paixóes próprias do campo do político, e o resultado é a potencialização das violências e das sensibilidades políticas. Essa dinâmica, por si só, garante lugar de destaque para as fontes imagéticas e, também, espaço privilegiado para o campo da cultura no estudo e observação do objeto político, tanto na esfera da dominação e da autoridade quanto na da contestação e da resistência.

Essa preocupação com a tríade política - cultura - estética é perceptível na recente produção historiográfica, cada vez mais voltada à utilização de imagens para a compreensão dessa interseção entre os campos cultural e político. O cinema, ${ }^{46}$ as charges ${ }^{47}$ e a arte em geral $^{48}$ são apenas três dos aspectos mais evidentes dessa perspectiva, fomentada pela reestruturação da História Cultural e da História Cultural do Político. ${ }^{49}$

Diante desse cenário, apresentamos neste artigo o método documentário como alternativa no trato metodológico das fontes visuais. O ponto central do método documentário, que foi aqui discutido e apresentado de forma empírica, é a inversão da questão elementar na pesquisa, passando-se do "o que" (was) a fonte é ou representa para o "como" (wie) determinada fonte foi produzida. Como pudemos demonstrar, tal mudança de perspectiva conduz a uma maior amplitude na concepção e realização da pesquisa, possibilitando a abertura de horizontes e possibilidades que antes poderiam estar eclipsados para o pesquisador. Em outras palavras, o processo não apenas leva a uma classificação e análise metodológicas da fonte, mas traz à tona questóes a serem exploradas que antes passariam despercebidas. Mostra-se assim não apenas uma ferramenta eficaz no arrolamento e na interpretação dos diferentes elementos constitutivos da imagem, mas também uma estrutura teórico-metodológica de instigação e de orientação.

Essa caracterização do método como ferramenta de pesquisa para o historiador não infere que os seus passos resultem em uma condição especial na produção de conhecimento.

${ }^{45}$ GOMBRICH, Ernst. The mask and the face: the perception of physiognomic likeness in life and art. In: GOMBRICH, Ernst et al. (Ed.). Art, Perception, and Reality. Baltimore: John Hopkins University Press, 1972, p. 87.

${ }^{46}$ Dentre os vários exemplos da produção recente, destacamos CAPELATO, Maria Helena; NAPOLITANO, Marcos; SALIBA, Elias Tomé; MORETTIN, Eduardo. (Org.). História e cinema. São Paulo: Alameda, 2011; PEREIRA, Wagner Pinheiro. O poder das imagens. São Paulo: Alameda, 2014; VILLAÇA, Mariana. Cinema cubano - revolução política e cultural. São Paulo: Alameda, 2010; e SELIPRANDY, Fernando. A luta armada no cinema. São Paulo: Intermeios, 2015.

${ }^{47}$ LUSTOSA, Isabel (Org.). Imprensa, humor e caricatura: a questáo dos estereótipos culturais. Belo Horizonte: UFMG, 2011; MOTTA, Rodrigo Patto Sá. Jango e o Golpe de 1964 na caricatura. Rio de Janeiro: Jorge Zahar, 2006; e SILVEIRA, Mauro César. A batalha de papel - a charge como arma na guerra contra $o$ Paraguai. Florianópolis: Ed. UFSC, 2009.

${ }^{48}$ CALIRMAN, Claudia. Arte brasileira na ditadura militar. Rio de Janeiro: Réptil, 2014; USUBIAGA, Viviana. Imágenes inestables. Buenos Aires: Edhasa, 2012.

${ }^{49}$ MERGEL, Thomas. Kulturgeschichte der Politik. In: Docupedia-Zeitgeschichte. 11 fev. 2010. Disponível em: <https://docupedia.de/zg/Kulturgeschichte_der_Politik?oldid=75525>. Acesso em: 17 out. 2014. 
De fato, como todo método, ele apresenta uma sequência de passos que qualificam o acesso do pesquisador ao conhecimento, possibilita um acesso privilegiado às estruturas que percorrem a fonte e a sustentam. Toda imagem é uma testemunha de seu tempo, de seu grupo produtor, e como tal é um possível artefato de memória. Uma charge, como o exemplo aqui analisado, não é apenas uma ilustração humorística ou uma visão opinativa, mas pode também agir como eficiente propaganda ideológica ou como um ator político. Cada charge carrega em si a vocação do julgamento, e através desse exercício (pelo humor e/ou pela violência) no campo público do político, torna-se um agente de sua realidade. Esse intento de marcação e de alteração de sua realidade é sua característica pública mais evidente. Mas enquanto artefatos públicos, suas mensagens, seus ataques e seus preconceitos são também gritos por uma determinada memória, e carregam consigo as subjetividades inerentes a esses testemunhos. Em sua reconstrução, uma imagem aparentemente satírica de um judeu evidencia elementos formadores de uma identidade comunal nazista, uma convocação por uma ação pública e violenta contra os judeus e, em um nível mais aprofundado, um convite à aceitação da manipulação da realidade persecutória antissemita, escusando-a e mesmo justificando-a. Mais que uma propaganda ou uma piada, o que se revela é um testemunho, uma evidência do modus operandi do pensar e do agir nazistas.

O método documentário aqui apresentado possibilita que as estruturas mentais e práticas, de ordem social, econômica e política, sejam evidenciadas e, assim, não apenas a fonte seja analisada por ela mesma, mas também em sua própria conjuntura, através de sua reconstrução, e também enquanto artefato/testemunha histórica, sendo demostradas a partir de sua "decomposiçáo" as formas de concepção de si e de seus interpares. É importante frisar ainda que o foco do método recai na reconstrução da imagem, ou seja, em decodificar seus elementos constitutivos revelando as estruturas mentais e praxiológicas que as permeiam, mostrando o modo como são construídas as mensagens, os hábitos e as visóes de mundo. Assim, o método auxilia-nos a ampliar nosso entendimento sobre a forma de constituição do próprio contexto no qual a fonte foi produzida - e o qual é, inevitavelmente, por ela também produzido.

\section{Referências bibliográficas}

ACCARDO, Alain et. al.Journalistes au quotidien - Outils pour une socioanalyse des pratiques journalistes. Bordeaux: Le Mascaret, 1995.

. A estranha ética dos jornalistas. Le Monde Diplomatique, jan. 2003. Disponível em: $<$ http://www.diplo.com.br/aberto/0005/24.htm>. Acesso em: 12 fev. 2003.

ARENDT, Hannah. Origens do totalitarismo. São Paulo: Companhia das Letras, 2000.

BERGSON, Henri. O riso. São Paulo: Martins Fontes, 2001. 
BOHNSACK, Ralf. Qualitative Bild- und Videointerpretation. Opladen: Budrich, 2009. . Rekonstruktive Sozialforschung. Opladen: Budrich, 2007.

BOURDIEU, Pierre. Le sens pratique. Paris: Les Éditions de Minuit, 1980.

BYTWERK, Randall L. Julius Streicher - Nazi Editor of the notorious anti-semitic newspaper Der Stürmer. Nova York: Cooper Square, 2001.

CALIRMAN, Claudia. Arte brasileira na ditadura militar. Rio de Janeiro: Réptil, 2014; USUBIAGA, Viviana. Imágenes inestables. Buenos Aires: Edhasa, 2012.

CAPELATO, Maria Helena; NAPOLITANO, Marcos; SALIBA, Elias Tomé; MORETTIN, Eduardo (Org.). História e cinema. São Paulo: Alameda, 2011.

CASTORIADIS, Cornelius. A instituiçâo imaginária da sociedade. Rio de Janeiro: Paz e Terra, 1982.

CHARIM, I. Der negative Fetisch - Zur Funktionsweise rassistischer Stereotype. In Jüdisches Museum Berlin. Typisch! Klischees von Juden und Anderen — Katalog der Ausstellung. Berlim/Viena: 2008.

DIDI-HUBERMAM, Georges. A imagem sobrevivente - história da arte e tempo dos fantasmas segundo Aby Warburg. Rio de Janeiro: Contraponto, 2013.

EISNER, Will. Quadrinhos e arte sequencial. São Paulo: Martins Fontes, 1995.

FRANCO JR., Hilário. Cocanha - a história de um país imaginário. São Paulo: Companhia das Letras, 1998.

GOLDENSOHN, Leon. The Nuremberg Interviews. Londres: Pimlico, 2007.

GOLOMSTOCK, Igor. Totalitarian Art. Nova York: Overlook, 2011, p. 6.

GOMBRICH, Ernst. Kunst \& Illusion - Zur Psychologie der bildlichen Darstellung. Berlim: Phaidon, 2004.

. The mask and the face: the perception of physiognomic likeness in life and art. In: GOMBRICH, Ernst et al. (Ed.). Art, Perception, and Reality. Baltimore: John Hopkins University Press, 1972.

IMDAHL, M. Gioto - Arenafresken. Ikonographie - Ikonologie - Ikonik. Munique: Fink, 1988.

LIEBEL, Vinícius. Politische Karikaturen und die Grenzen des Humors und der Gewalt. Opladen: Budrich Unipress, 2011.

LONGERICH, Peter. "Davon haben wir nichts gewusst!" - Die Deutschen und die Judenverfolgung 1933-1945. Munique: Pantheon, 2007.

LUSTOSA, Isabel (Org.). Imprensa, humor e caricatura: a questão dos estereótipos culturais. Belo Horizonte: UFMG, 2011.

MANDROU, Robert. Introduction à la France moderne, 1500-1640. Essai de psychologie historique. Paris: A. Michel. 1998. 
MANNHEIM, Karl. Strukturen des Denkens. Frankfurt am Main: Suhrkamp Verlag, 1980. . Wissenssoziologie - Auswahl aus dem Werk. Berlim/Neuwied: Luchterhand, 1964. MERGEL, Thomas. Kulturgeschichte der Politik. In: Docupedia-Zeitgeschichte. 11 fev. 2010. Disponível em: <https://docupedia.de/zg/Kulturgeschichte_der_Politik?oldid=75525>. Acesso em: 17 out. 2014.

MITCHELL, William John Thomas. Picture Theory. Chicago: Chicago University Press, 1994.

MOTTA, Rodrigo Patto Sá. Jango e o Golpe de 1964 na caricatura. Rio de Janeiro: Jorge Zahar, 2006.

PANOFSKY, Erwin. Ikonographie \& Ikonologie. Colônia: Dumont, 2006.

PEREIRA, Wagner Pinheiro. O poder das imagens. São Paulo: Alameda, 2014.

RANCIÈRE, Jacques. A partilha do sensivel. São Paulo: Editora 34, 2009.

SELIPRANDY, Fernando. A luta armada no cinema. São Paulo: Intermeios, 2015.

SILVAIN, Gérard; KOTEK, Joël. La Carte Postale Antisémite. De l'affaire Dreyfus à la Shoah. Paris: Berg International, 2005.

SILVEIRA, Mauro César. A batalha de papel - a charge como arma na guerra contra o Paraguai. Florianópolis: Ed. UFSC, 2009.

VILLAÇA, Mariana. Cinema cubano - revolução política e cultural. São Paulo: Alameda, 2010.

WARBURG, Aby. Dürer e a Antiguidade italiana. In: WARBURG, Aby. Histórias de fantasmas para gente grande. São Paulo: Companhia das Letras, 2015.

WELLER, Wivian. A contribuição de Karl Mannheim para a pesquisa qualitativa: aspectos teóricos e metodológicos. Sociologias, Porto Alegre, n. 13, jan-jun. 2005. Disponível em: $<$ http://www.scielo.br/scielo.php?script=sci_arttext\&pid=S1517-45222005000100011 >. Acesso em: 16 out. 2012. . Minha voz é tudo que tenho. Belo Horizonte: EdUFMG, 2011. 